\title{
REPRESENTASI KUCING DALAM FOKLOR SUNDA
}

\author{
CAT REPRESENTATION ONSUNDANESE FOLKLORE
}

\author{
Ani Rostiyati \\ Balai Pelestarian dan Nilai Budaya Jawa Barat \\ Jl. Cinambo No. 136 Ujungberung - Bandung \\ E-mail: anirostiyati@yahoo.com \\ DOI: $10.36424 / j p s b . v 6 i 1.167$
}

Naskah Diterima: 14 April 2020 Naskah Direvisi: 21 Mei 2020

Naskah Disetujui: 21 Mei 2020

\begin{abstract}
Abstrak
Penggambaran kedekatan kucing terdapat dalam berbagai folklor di berbagai belahan dunia. Pada masyarakat Sunda, kedekatan tersebut direpresentasikan dalam folklor lisan Nini Anteh dan permainan tradisional anak. Namun, kajian mendalam tentang keterkaitan keberadaan kucing dalam folklor lisan cerita rakyat Nini Anteh dan permainan tradisional anak belum pernah dilakukan. Oleh sebab itu, tujuan kajian ini adalah mengungkap representasi kucing dalam foklor lisan tersebut. Adapun metode penelitian adalah deskriptif-kualitatif dengan pengambilan data melalui studi pustaka serta wawancara mendalam pada informan yang dianggap memiliki enkulturasi penuh. Data yang telah diperoleh kemudian dianalisis meliputi alur, makna, dan fungsinya. Hasil dari analisa tersebut diperoleh bahwa kata kucing dalam permainan tradisional anak merepresentasikan identitas budaya lokal dan kolektif bagi masyarakat Sunda serta media pendidikan bagi anak. Sedangkan kucing dalam cerita rakyat Nini Anteh dipandang sebagai subjek yang penting sebagai representasi dari domestikasi Nini Anteh yang menempatkan perempuan sebagai subordinat dari laki-laki dan menimbulkan ketimpangan sosial berbasis identitas gender.
\end{abstract}

Kata kunci: representasi, kucing, dan folklor Sunda.

\section{Abstract}

Depictions of cats are found in various folklore in various parts of the world. In Sundanese society, this closeness is represented in Nini Anteh's oral folklore and children's traditional games. However, in-depth study of the relationsip between the presence of cats in the oral folklore of Nini Anteh folklore and children's traditional games has never been done. Therefore, the aim of this study is to reveal the cat's representation in the oral folklore. The descriptive-qualitative research method by taking data through literature studies and in-depth interviews is performed with informants who are considered to have full enculturation. The data that has been obtained is then 
analyzed including the flow, meaning, and function. The results of the analysis show that the word "cat" in traditional children's games represents the local and collective cultural identity for the Sundanese community and the educational media for children. Whereas cats in Nini Anteh folklore are seen as important subjects as a representation of the domestication of Nini Anteh which places women as subordinates of men and creates social inequalities based on gender identity.

Keywords: representation, cat, and Sundanese folklore.

\section{PENDAHULUAN}

Kucing merupakan hewan yang dianggap dekat dengan perempuan. Penggambaran kedekatan tersebut dapat kita lihat dari berbagai folklor lisan. Misalnya saja melalui folklor lisan pada masyarakat Mesir, Jepang, Inggris, Cina, dan Indonesia. Di Mesir, kucing dianggap sebagai Dewa Kasih Sayang dan Kesuburan. Namanya Dewa Bastet atau Bast, yaitu dewa dengan kepala kucing, sedangkan tubuhnya berbentuk seorang perempuan (Praptanto, 2002: 85). Di Jepang, kucing dipercaya sebagai hewan kesayangan Dewa Amaterasu. Mereka percaya bahwa kucing merupakan utusan dewa yang turun ke bumi untuk menemukan orang yang berhati mulia namun sangat miskin, ia akan melaporkannya kepada Dewa Kemakmuran agar orang tersebut diberi rejeki. Di Inggris, penganut wicca dan neopaganisme mempercayai bahwa kucing mampu berhubungan dengan dunia lain dan dapat merasakan adanya roh jahat (Yulianto,2003). Kucing hitam, kerap kali diidentikkan dengan keberadaan penyihir perempuan.

Di Indonesia pun terdapat gambaran yang erat antara kucing dan perempuan. Misalnya saja di Sulawesi, Banjar (Kalimantan Selatan), dan Jawa Barat. Di Sulawesi terdapat folklor lisan mengenai Dewi Padi. Dalam folklor lisan tersebut, digambarkan bahwa kucing (Meong Mongpolo) adalah hewan yang setia pada Dewi Padi. Di Banjar terdapat folklor lisan Kucing Belaki Raja (Sulistiati, 1994). Dalam folklor tersebut diceritakan bahwa kucing adalah jelmaan bidadari yang mampu memberikan 41 anak pada raja.

Dalam beberapa cerita di atas terlihat bahwa kucing merupakan hewan terdekat dengan perempuan yang merupakan dewi dan menyimbolkan segala 
kebaikan. Berbeda dengan kepercayaan di Mesir, Jepang, Cina, Sulawesi, dan Banjar, di negara Barat justru kucing dekat dengan perempuan yang "jahat" (penyihir) yang kemudian kucing tersebut menjadi simbol kejahatan. Perbedaan tersebut menunjukkan bahwa kucing merupakan hewan yang memiliki dualisme (kebaikan dan kejahatan). Meskipun demikian, tetap saja, dualisme tersebut dikaitkan dengan keberadaan perempuan yang dekat dengannya.

Di Jawa Barat, pada masyarakat Sunda terdapat folklor lisan Nini Anteh. Folklor lisan adalah sebagian kebudayaan suatu kolektif, yang tersebar dan diwariskan secara turun-temurun, di antara macam kolektif apa saja, secara tradisional dalam versi yang berbeda-beda, dalam bentuk lisan (Danandjaja, 2002:13). Dalam Ensiklopedia Sunda (Ekadjati, 2000: 439), dijelaskan bahwa Nini Anteh adalah sebuah dongeng yang menceritakan bahwa bercak hitam yang tampak pada permukaan Bulan purnama itu adalah seorang nenek yang tiada henti menenun. Nenek tersebut disebut Nini Anteh. Ia disebut demikian karena kelihatan sedang memintal benang kantih (kanté). Ia selalu ditemani kucing kesayangannya, bernama Candramawat. Dalam Kamus Basa Sunda karya R.A. Danadibrata (2006: 28), dijelaskan bahwa Nini Anteh adalah bayangan seorang nenek yang sedang menenun. Bayangan terlihat pada saat bulan purnama.

Masyarakat Sunda juga mengenal permainan anak (kaulinan budak) yang menggunakan istilah hewan kucing (ucing). Salah satu hal menarik dari beragamnya permainan tradisional anak-anak Sunda adalah adanya keberadaan ucing. Ucing merupakan kata dalam bahasa Sunda untuk menyebut kucing. Pada kajian ini dibahas permainan anak yang menggunakan kata "ucing" untuk menyebut nama permainan tersebut. Dengan demikian, yang menjadi fokus kajian ini adalah bagaimana representasi hewan ucing (kucing) dalam foklor yang terdapat dalam cerita rakyat Nini Anteh dan permainan tradisional anak pada masyarakat Sunda. Makna apa yang terkandung dalam foklor tersebut dan bagaimana representasi kucing dalam folklor Sunda. 
Penelitian tentang Nini Anteh cukup banyak dilakukan oleh para peneliti. Penelitian mengenai Nini Anteh pernah dilakukan oleh Ampera dan Yostiani, berjudul "Nini Anteh Dalam Perspektif Von Daniken" (2007). Penulis mengemukakan bahwa Nini Anteh merupakan cerita yang menuturkan kisah perjalanan manusia bumi di luar angkasa, melalui sudut pandang penelitian ruang angkasa yang dikemukakan oleh Erick von Daniken dalam bukunya Kenangan Akan Masa Depan dan Kembali ke BintangBintang. Berdasarkan penelitian tersebut didapatkan simpulan mengenai simbol manusia bumi yang berhasil menjelajahi ruang angkasa.

Sementara itu, Yostiani (2009:14), dalam tulisannya yang berjudul "Kajian Struktur, Konteks Penuturan, Fungsi, dan Proses Penciptaan Cerita Nini Anteh di Kotamadya dan Kabupaten Bandung" mengungkapkan bahwa Nini Anteh merupakan figur perempuan yang memperoleh keseimbangan diri terhadap alam semesta. Cerita Nini Anteh juga dipandang sebagai inspirasi tentang pencapaian manusia untuk dapat menjelajahi ruang angkasa. Nini Anteh dalam berbagai versinya dikisahkan sebagai nenek yang aktivitasnya menenun atau memintal benang (kantéh) maupun kain. Ia selalu ditemani Candramawat, kucingnya yang setia. (Ekadjati, 2000; Danadibrata, 2006; Wiramihardja, 2013; Harini, 2015; Harini, 2016; ). Cerita Nini Anteh merupakan sebagian kebudayaan kolektif masyarakat Sunda yang tersebar dan diwariskan turun-temurun secara lisan. Dongeng ini biasanya diceritakan saat anak mau tidur dan saat mau bulan purnama. Orang tua biasanya mengatakan "Nini Anteh"nya belum datang sebentar lagi sambil membawa anaknya untuk melihat bulan.

Sebagai folklor lisan, cerita Nini Anteh dapat diklasifikasikan ke dalam legenda menurut Rusyana (2000:21) karena jalan cerita, tokoh, latar tempat dan waktu dapat dibayangkan seperti dalam kehidupan sehari-hari, namun terdapat pula hal yang mengandung keajaiban. Dalam konteks cerita Nini Anteh, hal yang mengandung keajaiban adalah peristiwa perempuan (Nini Anteh) yang berasal dari bumi yang mampu pergi dan menetap di bulan. Selain itu, cerita ini pun dianggap sebagai kisah yang benar-benar 
terjadi. Sosok Nini Anteh dalam 14 versi dikisahkan sebagai sosok perempuan mandiri.

Sosok Nini Anteh bagi masyarakat Sunda bukan hanya saja terdapat dalam cerita rakyat tetapi juga ada yang dalam bentuk uga (ramalan) bahwa akan ada orang yang sampai ke bulan. Baru pada tahun 1969, Neil Armstrong dan M. Collins (astronot Amerika) berhasil pergi dan menginjakkan kakinya di bulan. Dari hal tersebut, dapat dilihat bahwa masyarakat Sunda, sebagai folk cerita Nini Anteh, sudah berimajinasi bahwa suatu hari nanti bulan atau luar angkasa dapat dijelajahi.

Bagi masyarakat Sunda, sosok Nini Anteh begitu melekat dalam ingatan. Hal ini terbukti dari adanya lagu permainan anak saat ngabungbang (memuliakan Nini Anteh saat bulan purnama), misalnya saja dalam lagu Cing Cangkeling, dan Bulan Tok (Sunaryo, 2009; Suryawan, 2015; dan Aminudin, 2016). Selain itu juga menjadi inspirasi bagi pencipta karya sastra, cerpen, pupuh dan novel untuk menulis kisah Nini Anteh. Transformasi dari tradisi lisan ke tradisi tulis mulai dilakukan tahun 2000. Selain itu, Nini Anteh juga ditulis Rostiyati dan Harini (2018) tentang keterdidikan perempuan Sunda yang mengungkapkan bahwa Nini Anteh sebagai perempuan terdidik mampu mencapai kesetaraan gender, bahkan dirinya mampu mencapai derajat yang tinggi dengan kemandirian yang dimilikinya.

Berdasarkan penelusuran terhadap beberapa penelitian terdahulu, tampak masih ada yang luput dari perhatian peneliti yaitu tidak membahas secara spesifik mengenai representasi kucing dalam folklor lisan Nini Anteh. Padahal, dalam folklor tersebut tampak adanya hubungan yang erat antara perempuan (Nini Anteh) dengan kucing.

Selain kedekatan kucing dengan perempuan dalam cerita Nini Anteh, tampak pula kedekatan kucing dalam permainan tradisional anak Sunda. Ucing batu, ucing beling, ucing dongko, ucing guliweng, ucing hui, ucing jeblang panto, ucing jidar, ucing kuriling, ucing sendal, ucing sumput, ucing pengpeun, dan ucing-ucingan, merupakan permainan tradisional anak yang di dalamnya merepresentasikan kucing dalam budaya Sunda. Banyaknya 
permainan tradisional anak di Sunda yang dimulai dengan kata kucing (ucing) memunculkan pertanyaan mengapa kucing (ucing) yang dijadikan ikon dari permainan tersebut.

Penelitian mengenai keterkaitan antara keberadaan kucing dalam folklor lisan cerita rakyat Nini Anteh dan permainan tradisional anak, sepemahaman penulis belum dilakukan. Oleh sebab itu, pada penelitian ini dibahas mengenai representasi kucing dalam folklor tersebut.

Penelitian ini menggunakan teori ekofeminisme dari Tong (2010) yang menjelaskan bahwa perempuan ada keterkaitan dengan alam, ada hubungan simbolik dan linguistik antara feminis dan isu ekologi. Ada asumsi dasar pemikiran yang dibentuk oleh bingkai pikir konseptual patriarkal yang opresif, bertujuan untuk membenarkan hubungan antara dominasi dan subordinasi yakni dominasi laki-laki terhadap perempuan. Menurut Warren dalam Prabasmoro (2016:72), berpikir patriarkis, dualistik, dan opresif telah merusak perempuan dan alam. Perempuan telah dinaturalisasi (alamiah) dan alam telah difeminisasi, maka sangat sulit untuk mengetahui kapan opresi berakhir. Warren menekankan bahwa perempuan dinaturalisasi saat digambarkan terhadap binatang, misalnya ular, kuda betina, anjing betina, dan kucing. Alam difeminisasi ketika dikuasai atau ditaklukkan, dipenetrasi oleh laki-laki. Jika laki-laki bisa menaklukkan atau menguasai alam, maka lakilaki juga akan menguasai perempuan. Apapun yang dapat dilakukan untuk menguasai alam juga bisa dilakukan untuk menguasai perempuan. Teori ini bisa untuk menjelaskan representasi kucing dalam foklor Nini Anteh yang dikaitkan dengan gender.

Sedangkan untuk menganalisis representasi kucing dalam permainan tradisional anak pada masyarakat Sunda menggunakan teori semiotika. Dalam ilmu hermeunitik dan semiotika dari Danesi (2010:107) mengatakan bahwa sebuah tanda adalah sesuatu yang merepresentasikan sesuatu dalam pandangan tertentu, berupa isyarat atau lambang. Teori ini menjelaskan representasi kucing dalam permainan anak tersebut, makna apa yang terkandung dalam permainan anak tersebut. Dengan demikian fokus kajian ini 
adalah bagaimana representasi kucing dalam folklor lisan cerita Nini Anteh dan permainan tradisional anak pada masyarakat Sunda.

\section{METODE PENELITIAN}

Penelitian ini menggunakan metode deskriptif analitis seperti yang dikemukakan Ratna (2013). Hal tersebut dilakukan untuk memperoleh pemahaman melalui penelitian kebudayaan yang tidak datang dengan sendirinya ataupun dinyatakan langsung oleh realitas budayanya, tetapi direfleksikan, ditafsirkan atau diinterpretasikan, dan direkonstruksi oleh peneliti. Penulis menentukan ruang lingkup penelitian dengan fokus folklor yaitu permainan anak (kaulinan budak) dan cerita rakyat (Nini Anteh). Dengan alasan karena cerita rakyat Nini Anteh dan kucing yang selalu bersamanya, merupakan kebudayaan kolektif masyarakat Sunda yang sangat dikenal dan tersebar diwariskan turun-temurun secara lisan pada generasinya. Demikian pula permainan tradisional anak pada masyarakat Sunda lebih banyak menggunakan kata ucing pada permainan tersebut. Hasil penelitian Satriana (2017:39) mengumpulkan 20 permainan tradisional anak berbasis budaya Sunda yang menggunakan kata $u$ cing.

Adapun pengumpulan data yang melalui studi pustaka, observasi, dan wawancara mendalam pada dua informan bernama Ibu Yanah Nurjanah (65 tahun) yang tinggal di Ujung Berung dan Candra Kudapawana (62) tinggal di Subang. Ibu Yanah dan Candra Kudapawana mendapat cerita Nini Anteh dari kakek dan neneknya, menjelang tidur malam atau saat bulan purnama.

Setelah data diperoleh, penulis mengategorikan dan mengolah data. Proses analisis dalam penelitian ini dilihat mulai dari alur, makna, dan fungsi dalam cerita rakyat Nini Anteh dan permainan tradisional anak terhadap representasi kucing dalam folklor tersebut. Analisis menggunakan pendekatan semiotika dan hermeneutika dari Danesi (2010) untuk menginterpretasikan hewan kucing sebagai sebuah simbol yang memiliki makna penting bagi masyarakat Sunda. Hermeneutika adalah satu jenis teori filsafat yang mempelajari tentang interpretasi makna, yang berarti menafsirkan, memberi 
pemahaman atau menerjemahkan. Menurut Ahimsa (2010:26) dalam menganalisa sebuah cerita rakyat misalnya, bisa menggunakan perspektif antropologi hermeneutik dan interpretatif, yakni menggunakan "teks" sebagai analogi atau model yang memandang, memahami, dan menafsirkan suatu kebudayaan atau gejala sosial budaya tertentu. Peneliti tidak akan memberikan "penjelasan" atau explanation, tetapi akan melakukan "pembacaan" atas gejala sosial budaya tersebut, dan itu berarti peneliti akan memberikan tafsir-tafsir tertentu. Tentu saja kadang bersifat subyektifitas, karena setiap penafsiran selalu berada dalam atau berawal dari kerangka berfikir individual tertentu. Dalam konteks seperti itu, maka istilah "ilmiah" tidak bisa lagi diberi makna yang sama dengan jika melakukan penelitian di lapangan.

\section{PEMBAHASAN}

\section{Representasi Kucing dalam Folklor Lisan Masyarakat Sunda}

Cerita Nini Anteh tersebar dalam bentuk folklor lisan. Jika digolongkan lebih lanjut, cerita Nini Anteh termasuk ke dalam dongeng. Dongeng dianggap masyarakat hanya sebagai kisah pelipur lara. Karena tidak dianggap sebagai kisah yang sakral dan tidak beredar dalam bentuk wawacan $^{1}$ sehingga tukang beluk ${ }^{2}$ tidak membelukkannya, banyak masyarakat yang tidak mengetahui kisah ini secara detail. Masyarakat Sunda yang diwawancarai, mayoritas hanya mengetahui bahwa Nini Anteh ialah karakter dalam dongeng dan berada di bulan ditemani kucingnya. Mengenai

\footnotetext{
${ }^{1}$ Wawacan merupakan karangan panjang yang digubah dalam bentuk puisi pupuh. Umumnya berisi cerita yang banyak jumlahnya dengan alur panoramik. Masa yang dilukiskannya biasanya meliputi jangka waktu yang panjang, sering tidak menghiraukan kronologi. Para pelaku cerita pun berjumlah banyak, bukan saja manusia, melainkan juga jin, siluman, raksasa, dan lain-lain, sering diberi kekuatan yang luar biasa (Rusyana, 1997: 244).

${ }^{2}$ Beluk adalah seni membacakan wawacan. Syair yang dilantunkan adalah jenis wawacan (carita babad) yang dibawakan seperti dijumpai dalam beberapa pupuh mulai dari pembukaan sampai pada penutupan seperti pupuh kinanti, asmarandana, pucung, dangdanggula, balakbak, magatru, mijil, dan ladrang. Adapun jenis wawacan yang disampaikan juru beluk bergantung pada yang diikuasainya seperti wawacan ogin, rengganis, babar nabi, barjah, amungsari, jayalalana, natakusuma, lutung kasarung, mahabarata, dan ciung wanara (Widiagiri, 2011).
} 
alasan keberadaan Nini Anteh di bulan, bahkan asal muasal Nini Anteh banyak yang tidak mengetahuinya. Beberapa versi cerita kumpulkan, dipilih cerita Nini Anteh yang lengkap ${ }^{3}$.

Salah satu cerita Nini Anteh yang lengkap dituturkan oleh Candra Kudapawana, salah seorang informan yang tinggal di Subang, mengatakan bahwa Candra Kudapawana menuturkan bahwa Nini Anteh merupakan penduduk bumi. Ia memiliki suami bernama Aki Anteh. Nini Anteh memiliki seekor kucing bernama Candramawat. Nini Anteh, Aki Anteh, dan Aki Bentar terlibat cinta segitiga. Suatu hari Aki Anteh pergi kemudian dicari oleh Nini Anteh hingga akhirnya Nini Anteh tersesat di bulan. Untuk mengobati kerinduan pada Aki Anteh, Nini Anteh selalu memainkan kecapi di bulan. Nini Anteh mengutus Candramawat untuk mencari Aki Anteh di bumi. Sayangnya, usaha Candramawat dihalangi oleh Aki Bentar. Aki Bentar yang memiliki kekuatan mengeluarkan halilintar, senantiasa mengejar Candramawat (kucing berekor bengkok yang membawa pesan Nini Anteh untuk Aki). Candramawat ini adalah seekor kucing kesayangan Nini Anteh. Kucing yang memiliki porsi peran yang seimbang dengan karakter Nini Anteh. Cerita tersebut akan ditelusuri terlebih dahulu alurnya, kemudian melalui alur tersebut apakah merepresentasikan adanya masalah gender.

Untuk dapat melihat bagaimana pengoperasian gender tersebut, kita dapat melihatnya dari alur teks. Hal ini terjadi karena rmasalah gender merupakan sesuatu yang diproduksi secara kultural. Dengan melihat pengoperasian gender dalam alur cerita Nini Anteh, kita akan dapat melihat siapakah yang diposisikan sebagai subjek. Apakah perempuan yang ditempatkan sebagai subjek ataukah laki-laki? Menurut Minh-ha (1989:130), perempuan menempati posisi yang sangat rumit dalam memposisikan dirinya sebagai subjek. Selain dilihat berdasarkan penempatan subjek, juga akan melihat bagaimana kaitan antara perempuan, laki-laki, dan alam dalam cerita Nini Anteh.

\footnotetext{
${ }^{3}$ Maksud lengkap adalah cerita Nini Anteh yang menjelaskan asal muasal Nini Anteh sebagai perempuan bumi yang kemudian mampu pergi dan menetap di bulan. Kemudian, dalam cerita tersebut terdapat pula alasan keberangkatan Nini Anteh.
} 
Alur cerita Nini Anteh terbentuk secara linier sehingga memunculkan pemaknaan sebagai pemilik lore tersebut. Kita dapat melihat bagaimana pembentukkan alur dan karakter dalam cerita Nini Anteh ini, karena tiap dongeng senantiasa beralur linier. Hal ini didasarkan pada pertimbangan penutur dongeng. Dongeng Nini Anteh ini diperuntukkan bagi anak-anak, sehingga alur linier sangat memudahkan anak untuk memahami sebuah cerita. Pengaluran yang dibuat tidak berujung ini menarik untuk membuat penutur dan petutur berada dalam konteks cerita tersebut, sehingga nilai yang terkandung dalam cerita tersebut dapat dilestarikan .

Cerita Nini Anteh menempatkan Nini Anteh sebagai subjek. Berbeda dengan cerita Jaka Tarub yang juga bercerita tentang keberadaan perempuan di bulan. Dalam cerita Jaka Tarub, yang menjadi subjek adalah Jaka Tarub (laki-laki), bukan Nawang Wulan (perempuan). Nawang Wulan merupakan objek bagi Jaka Tarub. Hal ini dapat menunjukkan bahwa masyarakat Sunda dalam folklor Nini Anteh turut membangun konstruksi mengenai perempuan dan laki-laki. Hal ini bisa dilihat dari karakter Nini Anteh yang mencintai Aki Anteh, berusaha mencari Aki Anteh dengan bantuan Candramawat bermain kacapi untuk mengobati rindu. Hubungan Nini Anteh dengan seekor kucing bernama Candramawat ini sangat dekat. Sedangkan karakter Aki Anteh yang mencintai Nini Anteh bersifat pasif, tidak berusaha mencari Nini Anteh. Hubungan Aki Anteh dengan kucing Candramawat tidak dekat. Adapun karakter Aki Bentar yang mencintai Nini Anteh dan membenci Aki Anteh, berusaha aktif menghalangi Candramawat menemui Aki Anteh. Hubungan Aki Bentar dengan Candramawat tidak baik bahkan membencinya.

Penempatan perempuan Sunda sebagai subjek dalam cerita Nini Anteh digambarkan sebagai perempuan yang berinisiatif untuk mencari Aki Anteh. Berbeda dengan suaminya, Aki Anteh sama sekali tidak digambarkan berusaha untuk mencari Nini Anteh. Karakter Nini Anteh digambarkan bermain kacapi di bulan untuk mengobati rasa rindunya. Ada hal menarik di sini, karena biasanya dalam masyarakat Sunda yang bermain kacapi adalah laki-laki sedangkan perempuan adalah menembang (bernyanyi). 
Penggambaran seperti ini dapat dilihat sebagai wacana tandingan terhadap apa yang terjadi di dunia nyata, di mana laki-lakilah yang bermain kacapi.

Wacana tandingan ini, rupanya terjadi pula pada penggunaan nama sebutan. Biasanya nama orang tua yang sudah memiliki anak, akan berubah sesuai nama anaknya. Atau, kalau orang tua tersebut tidak memiliki anak, maka nama sebutannya adalah berdasarkan sifatnya. Dalam cerita Nini Anteh, nama perempuan memang didasarkan pada sifatnya yang tengah memintal kisah kehidupan (yang diasumsikan seperti memintal benang). Sedangkan nama Aki Anteh, digambarkan sebagai pemberian karena dirinya adalah suami Nini Anteh.

Meskipun demikian, penggambaran Nini Anteh sebagai subjek ini menjadi terbatas, karena yang membuat terbatas adalah dirinya terdomestikasi. Hal ini terlihat dari tidak bisanya Nini Anteh pergi dari bumi. Nini Anteh tidak bisa pergi ke bumi karena di bumi ada Aki Bentar yang begitu menakutkan. Nini Anteh terepresi oleh Aki Bentar. Nini Anteh menyuruh kucingnya untuk turun ke bumi untuk menemui Aki Anteh. Keberadaan Candramawat yang dapat pergi ke bulan atau pun pergi ke bumi menunjukkan hal yang tidak bisa dilakukan oleh Nini Anteh.

Nini Anteh digambarkan tersesat hingga akhirnya dia sampai di bulan. Kata "tersesat" menunjukkan bahwa bulan bukanlah tempat yang diinginkan Nini Anteh. Meskipun bulan berada di atas bumi (jika dilihat dari bumi). Hal ini merupakan simbol bahwa bulan adalah tempat yang tinggi. Tempat yang tinggi tersebut dapat pula diartikan sebagai "kurungan" bagi Nini Anteh, karena dirinya masih tetap merasakan kerinduan yang teramat sangat pada Aki Anteh. Bumi pun bukan tempat yang diinginkan Nini Anteh karena dirinya digambarkan "terusir dari bumi" demi mencari Aki Anteh.

Penggambaran tersebut menempatkan Nini Anteh pada posisi yang serba salah. Meskipun Nini Anteh berada pada posisi yang lebih tinggi daripada laki-laki dan melakukan "pekerjaan" yang biasanya dilakukan oleh laki-laki (memetik kecapi), tapi tetap saja Nini Anteh tersiksa dengan kerinduan dirinya pada Aki Anteh. Kerinduan terhadap seseorang yang tidak 
digambarkan merindukannya, ini dapat ditangkap sebagai simbol kerinduan terhadap laki-laki. Saya tidak yakin apakah kerinduan tersebut merupakan kerinduan Nini Anteh untuk dapat menikmati segala sesuatu yang dapat dinikmati laki-laki. Atau apakah ini dapat dikatakan seperti apa yang Freud katakan bahwa perempuan itu iri terhadap laki-laki.

Menurut teori Freud yang diambil dalam tulisan Tong (2010:35) tentang feminisme psikoanalisis mengatakan bahwa semasa kecil, perempuan selalu merasa memiliki organ kecil, tidak seperti laki-laki yang memiliki penis yang lebih menonjol dan mempunyai proporsi lebih besar dari perempuan. Sejak saat itu perempuan menjadi korban dari kecemburuan terhadap laki-laki (penis envy). Namun dalam perkembangannya, anak perempuan yang iri terhadap laki-laki, mulai menginginkan cinta dari lakilaki. Freud berteori bahwa sulit bagi anak perempuan untuk mencapai seksualitas dewasa yang normal. Berbeda dengan anak laki-laki yang cepat mendapatkan kenikmatan dari penisnya, meski perempuan lambat laun juga ingin mendapatkan kenikmatan seksualnya dari vagina yang "feminim".

Penggambaran laki-laki dalam cerita ini juga serba salah. Aki Anteh digambarkan sebagai laki-laki yang pasif, yang tidak melakukan apa-apa saat istrinya merindukannya. Bahkan tidak melakukan usaha agar dirinya dapat bertemu dengan istrinya. Penggambaran demikian, membuat Nini Anteh digambarkan sebagai perempuan yang menanggung rindu. Jadi dalam cerita ini, sikap Aki Anteh yang pasif ini menimbulkan kesengsaraan bagi Nini Anteh.

Dalam cerita ini digambarkan pula karakter laki-laki yang begitu aktif. Namun, keaktifan tersebut nyatanya digambarkan pula sebagai hal buruk, yang berdampak pada Nini Anteh tidak dapat bertemu dengan Aki Anteh dan Candramawat tidak dapat segera memenuhi keinginan Nini Anteh. Bahkan karakter Aki Bentar dalam cerita ini digambarkan begitu jahat. Dengan kekuatannya, dapat menghancurkan tempat persembunyian Candramawat seperti pohon-pohon menjadi hangus dan tumbang. Karakter Aki Bentar ini digambarkan sebagai penghancur alam baik itu tumbuhan maupun hewan 
(Candramawat). Berdasarkan sudut pandang teori ekofeminis, laki-laki memang dipandang sebagai "biang keladi” rusaknya alam. Candramawat yang digambarkan sebagai perwakilan Nini Anteh untuk mencari Aki Anteh di bumi, berusaha dikalahkan dan ditaklukkan oleh Aki Bentar. Candramawat, sebagai kucing yang digambarkan aktif membantu Nini Anteh dalam proses pencarian Aki Anteh dapat dipandang sebagai domestikasi Nini Anteh.

Berdasarkan paparan di atas, tampak bahwa dalam folklor lisan, Nini Anteh digambarkan sebagai subjek, sebagai perempuan yang dapat menentukan sikap, mencapai kedudukan yang tinggi (simbol bulan), dan melakukan pekerjaan yang biasa dilakukan oleh laki-laki-laki (simbol bermain kecapi). Meskipun demikian, posisi sebagai subjek tersebut justru membuat Nini Anteh tersiksa karena dirinya menanggung rindu pada Aki Anteh (pengurungan secara psikologis), sedangkan dirinya terepresi oleh keberadaan Aki Bentar yang menyebabkan dirinya tidak bisa pergi kemana pun. Keberadaan Candramawat merupakan simbol domestikasi Nini Anteh, karena Candramawat digambarkan dapat melakukan sesuatu yang tidak dapat dilakukan oleh Nini Anteh. Candramawat dapat pergi ke bumi untuk mencari Aki Anteh dan dapat pergi ke bulan sesuai kehendaknya..

\section{Representasi Kucing dalam Permainan Anak Sunda}

Permainan tradisional anak-anak Sunda sangat beragam (Satriana, 2017:12). Ada permainan yang menggunakan lagu sebagai bagian dari proses permainannya (misalnya paciwit-ciwit lutung). Ada pula permainan yang harus menggunakan alat sebagai sarana dalam permainan tersebut (misalnya congklak dan beklen). Kemudian, ada permainan yang dapat dimainkan jika pihak yang terlibat lebih dari dua orang anak (misalnya boy-boyan). Lalu, ada pula permainan yang dapat dimainkan di tempat yang terbatas (misalnya beklen dan congklak) tetapi ada pula permainan yang membutuhkan ruang yang luas (misalnya ucing-ucingan). Selain itu ada pula permainan yang 
diawali dengan proses penentuan pihak berlawanan (misalnya dalam permainan ucing-ucingan).

Salah satu hal menarik dari beragamnya permainan tradisional anakanak Sunda adalah adanya keberadaan ucing. Ucing merupakan kata dalam bahasa Sunda untuk menyebut kucing. Pada kajian ini dibahas permainan yang menggunakan kata "ucing" untuk menyebut nama permainan tersebut. Permainan yang dibahas ialah: 1) ucing batu; 2) ucing beling; 3) ucing jidar; 4) ucing dongko; 5) ucing guliweng; 6) ucing hui; 7) ucing kuriling; dan 8) ucing-ucingan. Permainan yang menggunakan kata "ucing" tersebut akan dipaparkan strukturnya terlebih dahulu baru kemudian dibahas representasinya. Representasi kucing dalam permainan ini kemudian dibandingkan dengan representasi kucing dalam folklor lisan Nini Anteh.

Berikut ini dibahas struktur permainan yang ada kata "ucing" dalam permainan tersebut.

\section{a. Ucing Batu}

Sumarna (1983: 55) mengungkapkan bahwa ucing batu ialah permainan yang menggunakan batu sebagai sarana permainannya. Permainan ini biasa dilakukan di sungai ataupun kolam yang dangkal. Sebelum memulai permainan, terlebih dahulu dipilih yang berperan sebagai ucing. Setelah ditentukan, kemudian pemain yang bukan berperan sebagai ucing mencari batu. Masing-masing pemain mengambil satu batu. Batu yang dipilih ialah yang tidak runcing agar tidak menusuk saat diinjak.

Setelah itu, batu tersebut disembunyikan di suatu tempat. Saat sedang menyembunyikan batu, sang ucing harus menenggelamkan dirinya agar tidak melihat di mana teman-temannya menyembunyikan batu yang menjadi kojonya. Jika sudah ditemukan kojo (batu) milik anak-anak itu, maka pemilik kojo yang pertama kali ditemukan itulah yang harus menjadi ucing dalam permainan selanjutnya. 


\section{b. Ucing Beling}

Permainan ucing beling tidak jauh berbeda dengan ucing batu. Sumarna (1983: 43) menuliskan bahwa hal pertama yang dilakukan anakanak dalam permainan ini adalah penentuan siapa yang berperan sebagai ucing. Anak yang kalah menjadi ucing. Setelah itu, anak-anak yang tidak menjadi ucing mencari beling yang dapat berupa pecahan piring, gelas, ataupun mangkuk. Masing-masing anak memiliki satu pecahan beling yang dijadikan kojo. Ucing harus menutup matanya sambil menunggu lawannya menyembunyikan belingnya di dalam tanah. Setelah semua beling disembunyikan, barulah ucing mencari beling tersebut. Pemilik beling yang belingnya ditemukan pertama kali oleh $u$ cing, dialah yang akan menjadi ucing selanjutnya.

\section{c. Ucing Jidar}

Sumiyadi (2009: 91) menuliskan bahwa nama permainan ini disinyalir berasal dari nama alat yang digunakan. "Jidar" dalam bahasa Sunda berarti penggaris atau alat ukur dengan kurang lebih $30 \mathrm{~cm}$, sedangkan ucing merupakan penyimbolan bahwa permainan ini merupakan permainan kompetisi, ada kawan dan ada lawan.

Anak-anak yang mengikuti permainan ini biasanya melakukan hompimpah terlebih dahulu untuk menentukan siapa yang menjadi ucing. Setelah ucing ditentukan, ucing memulai permainan dengan mengukur jidarnya dengan cara satu jidar dibiarkan diam sebagai batas dan satunya lagi digerakkan sebagai jidar sesuai dengan panjang batang yang dijadikan jidar. Jidar diukur menyerupai siku-siku kemudian setelah itu jidar didiamkan.

Anak-anak mulai bermain, satu persatu melangkahi batas jidar. Kemudian jika semua anak sudah berhasil melewati batas jidar tersebut maka mereka kembali ke tempat semula, sedangkan ucing mengulang kembali mengukur jidar. Anak-anak mengulang kembali melompati, begitu seterusnya sampai ada anak yang tidak mampu melompati dan kakinya terkena jidar. Jika hal tersebut terjadi, maka kedudukan ucing akan beralih pada pemain 
yang kakinya menyentuh jidar. Pemain yang kakinya kena jidar harus lari dan menangkap teman yang lainnya yang belum memasuki kawasan bebas gerak. Jika anak tersebut tidak bisa menangkap pemain yang lain, berarti dia tetap menjadi ucing.

\section{d. Ucing Dongko}

Sumiyadi (2009: 41) menuliskan bahwa permainan ini dinamakan ucing dongko karena pemain yang berperan sebagai ucing harus mengejar lawannya yang berdiri sebelum lawan tersebut berjongkok (dongko). Untuk menentukan pemeran ucing, telunjuk para pemain harus diletakkan di salah satu telapak tangan temannya. Saat lirik "ditembak ngajelegur" pemain siapsiap menarik jari telunjuk dari tangan temannya. Jika salah satu jari telunjuk terjepit oleh tangan temannya maka dialah yang menjadi ucing. Untuk menyelamatkan dirinya, lawan tersebut harus berjongkok untuk menghindar dari si ucing. Apabila lawan berdiri dan tersentuh oleh si ucing maka dia akan menjadi ucing pengganti pemeran ucing sebelumnya.

\section{e. Ucing Guliweng}

Sumiyadi (2009: 131) menuliskan bahwa permainan ini diawali dengan membuat garis berbentuk lingkaran sebanyak dua buah yang dihubungkan oleh semacam jembatan dari dua garis. Lingkaran yang satu tertutup dan yang satunya lagi terbuka. Setelah gambar lingkaran selesai dibuat, maka anak-anak melakukan hompimpah alaihum gambreng untuk menentukan siapa yang menjadi ucing. Pihak yang kalahlah yang menjadi ucing. Setelah itu yang menjadi ucing berusaha menyentuh atau memegang teman-temannya yang terdapat dalam lingkaran. Jika ada yang kena, maka anak yang kena akan menjadi ucing selanjutnya, sedangkan anak yang jadi ucing sebelumnya masuk ke dalam lingkaran bersama anak-anak lainnya. 


\section{f. Ucing Hui}

Sumiyadi (2009: 110) menuliskan bahwa dalam permainan ini, harus diundi terlebih dahulu siapa yang akan berperan sebagai ucing dan yang berperan sebagai urang lembur (orang desa). Anak terakhirlah yang akan menjadi ucing. Sementara itu urang lembur kemudian berjongkok sambil memegang pagar dengan sangat kuat. Pemenang undian yang pertama menjadi orang yang pertama dalam urutan memegang pagar atau pohon sambil berjongkok. Kemudian, orang kedua harus berpegangan erat pada orang pertama. Orang ketiga harus berpegangan erat pada orang kedua, dan seterusnya. Setelah semua berjongkok, sang ucing kemudian bernyanyi. Berikut adalah nyanyian yang biasa dinyanyikan ucing.

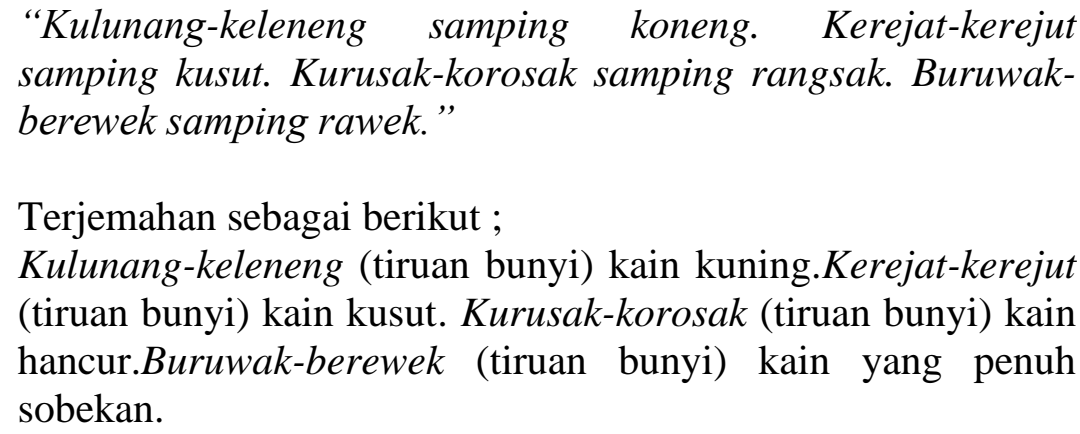

Setelah bernyanyi, ucing kemudian melakukan dialog dengan urang lembur yang kemudian menjadi ubi. Setelah itu, ucing kemudian bernyanyi kembali sambil mengelilingi "urang lembur" lalu bertanya kembali. Ucing kemudian melompat agak jauh dari urang lembur. Tak lama kemudian muncul ucing menarik ubi yang berjongkok paling belakang. Kalau lepas dari jajarannya, yang lain bergegas berlari. Kemudian ucing bergegas mengejar mereka satu persatu. Kalau sudah lelah, permainan ini dapat dihentikan.

\section{g. Ucing Kuriling}

Sumiyadi (2009: 182) menuliskan bahwa sebelum permainan dimulai, biasanya diadakan dahulu pemilihan ucing. Caranya, anak-anak yang akan bermain berkumpul terlebih dahulu untuk membuat semacam lingkaran, mengelilingi seorang anak yang lebih tua atau dituakan. Dalam permainan ini, 
anak yang berkeliling itu ditunjuk satu-satu oleh anak yang dituakan dengan melantunkan lagu Cingcangkeling.

Setiap suku kata dikenakan kepada seorang anak dan pada akhir kata "buleneng" berhenti di seorang anak, maka anak tersebut yang menjadi kucing, yang lainnya menjadi tikus. Kemudian serentak seluruh pemain masuk ke dalam lingkaran sedangkan ucing menempati garis lingkaran dan terus saja berusaha untuk menyentuh tikus yang ada dalam lingkaran. Jika ada tikus yang tertepuk, maka tikus itulah yang harus menggantikan posisi ucing. Tetapi tentu saja tikus-tikus itu tidak mau ditepuk begitu saja, mereka akan dengan lincah mengelak dan menghindar dari tepukan si ucing sambil mengeluarkan cemoohan-cemoohan kepada si ucing agar si ucing lebih jengkel sehingga lebih susah untuk mendapatkan mangsanya. Maka di dalam lingkaran itu akan terjadi dorong-mendorong antara tikus-tikus karena ketakutan.

Adakalanya tikus-tikus mendorong kawannya agar dapat dijangkau oleh si kucing. Maka dalam suasana inilah, sorak sorai, gelak tawa memenuhi arena itu diselingi dengan ocehan-ocehan tikus yang mengolok-olok sang kucing, manakala kucing itu tidak dapat mengenai sasarannya. Jika ternyata si kucing cekatan, maka ia akan segera dapat menyentuh tikus-tikus. Dengan demikian, ia pun bebas.

\section{h. Ucing-ucingan}

Sumiyadi (2009: 195) menuliskan bahwa permainan ini diawali dengan menyanyikan lagu sambil menunjuk peserta permainan sampai lagu berakhir. Saat lagu berakhir, peserta yang tertunjuklah yang menjadi "ucing", yang nantinya harus mengejar teman-teman lain yang berlarian. Dan saat "ucing" mengejar dan menangkap peserta permainan, peserta yang tertangkap akan menjadi "ucing" dan kembali mengejar teman-teman lain. Begitu seterusnya.

Berdasarkan paparan di atas, tampak beberapa kesamaan dalam permainan yang terdapat kata "ucing" dalam penamaannya. Persamaan 
tersebut salah satunya ialah sebelum memulai permainan, biasanya dimulai dengan menentukan siapa yang menjadi ucing. Penentuan siapa yang berperan sebagai ucing ini biasanya ditentukan berdasarkan lagu ataupun undian (misalnya hompimpah alaihum gambreng). Anak yang kalah kemudian harus menjadi ucing.

Seorang anak yang berperan sebagai ucing harus menanggung sejumlah konsekuensi. Dalam permainan itu, ucing harus dapat menemukan batu yang disembunyikan temannya di dalam air. Permainan ucing beling, ucing harus dapat menemukan batu yang disembunyikan temannya di dalam tanah. Permainan ucing jidar, ucing harus dapat mengukur dengan persis ukuran kemampuan teman-temannya dalam melangkahi jidar. Permainan dalam ucing dongko, ucing harus dapat mengejar temannya yang berlarian sebelum temannya tersebut dongko (jongkok). Permainan ucing guliweng, ucing harus dapat menyentuh teman-temannya yang berada dalam lingkaran. Permainan ucing hui, ucing harus dapat menarik dengan kuat orang yang berjongkok dan saling berpegangan pinggang. Permainan ucing kuriling, ucing harus dapat menyentuh teman-temannya yang berada dalam lingkaran. Permainan ucing-ucingan, ucing harus memiliki kemampuan berlari dengan kencang agar mampu mengenai atau menangkap teman-temannya yang berlarian.

Permainan tersebut menuntut ucing memiliki kemampuan fisik yang kuat. Ucing harus bisa berlari kencang, teliti, dan memiliki kekuatan. Selain itu, ucing harus memiliki kemampuan mengatur strategi agar tidak kehabisan energi agar ucing dapat melepaskan dirinya dari peran ucing untuk kemudian berubah menjadi pihak yang dikejar oleh ucing.

Apa yang sudah diungkapkan dalam permainan anak tersebut, ucing dipandang sebagai subjek. Meskipun peran sebagai ucing kerapkali dihindari dan menjadi bahan olok-olok teman dan dipersepsi sebagai sesuatu yang buruk, permainan ini justru merupakan sarana pembuktian diri bagi seseorang yang berperan sebagai ucing. Sang ucing berusaha mendayagunakan seluruh kemampuan dirinya agar dapat melepaskan diri dari peran ucing tersebut. 
Peran ucing yang disandang oleh anak yang kalah dalam undian, dapat dipandang sebagai sarana untuk bangkit dari keterpurukan. Saat dirinya mampu berlari kencang, teliti, memiliki strategi, dan memiliki energi tinggi, sehingga mampu menangkap atau menemukan sesuatu yang disembunyikan lawannya, dia dapat menanggalkan peran ucingnya. Ia dianggap sebagai pemenang dan penakluk anak lain yang kemudian harus menjadi ucing.

Apabila dilihat berdasarkan waktu yang digunakan saat bermain, permainan ini fleksibel. Anak-anak dapat memainkan permainan ini kapan saja. Meskipun demikian, biasanya permainan ini dilakukan saat jam istirahat sekolah ataupun saat pulang sekolah. Permainan dapat diakhiri apabila anak yang terlibat telah lelah atau permainan disepakati berakhir. Hal ini menunjukkan bahwa dalam permainan ini terdapat unsur demokrasi.

Permainan ucing ini membutuhkan tempat luas atau ruang terbuka yang memungkinkan anak-anak dapat berlarian atau menyembunyikan sesuatu. Tempat yang luas dapat melatih kemampuan fisik anak untuk mengeksplorasi gerak dan lingkungan sekitarnya. Dalam konteks ini, ucing direpresentasikan sebagai sosok yang harus memiliki kemampuan gerak dan memahami lingkungan sekitarnya.

Selain itu, pihak yang terlibat dalam permainan ini tidak dibedakan berdasarkan kelamin. Setiap anak baik perempuan maupun laki-laki dapat bermain bersama. Posisi perempuan dan laki-laki dipandang sama, yakni sama-sama berkesempatan menjadi ucing, sama-sama berkesempatan menjadi yang dikejar ucing. Dalam konteks ini terlihat bahwa permainan ini tidak bias gender. Perempuan dan laki-laki sama posisinya.

Permainan yang dalam penamaannya menggunakan kata "ucing" ialah permainan kolektif. Permainan ini tidak bisa dimainkan seorang diri. Semakin banyak pihak yang terlibat dalam permainan ini maka jalannya permainan akan semakin menarik. Dalam permainan masyarakat Sunda, kita tidak akan menemukan nama permainan yang dapat dimainkan seorang diri ataupun hanya berdua, yang menggunakan kata "ucing". Hal ini dapat dipandang bahwa ucing merupakan sesuatu yang direpresentasikan berkaitan dengan 
kolektif masyarakat. Menjadi kucing merupakan konsekuensi yang harus ditanggung saat kalah dalam pengundian. Meskipun peran sebagai ucing kerap kali dihindari dan menjadi bahan olok-olok teman sehingga dipersepsi sebagai sesuatu yang buruk, permainan ini justru merupakan sarana pembuktian diri bagi seseorang yang berperan sebagai ucing berusaha mendayagunakan seluruh kemampuan dirinya agar dapat bangkit dari keterpurukan.

\section{PENUTUP}

Berdasarkan paparan di atas, tampak bahwa kucing dalam folklor lisan Nini Anteh digambarkan mempunyai peran penting, karena keberadaan Candramawat (kucing) merupakan representasi dari domestikasi Nini Anteh. Nini Anteh yang seharusnya sebagai subjek tetapi hidup menderita dan terepresi. Pada akhirnya yang terbangun tersebut seringkali menempatkan perempuan sebagai objek subordinat dari laki-laki dan menimbulkan ketimpangan sosial berbasis identitas gender (Mecca, 2017). Laki-laki dianggap sebagai subjek dan perempuan sebagai objek (Liyan bagi laki-laki). Dalam foklor lisan Nini Anteh tersebut, secara sekilas terlihat kemandirian perempuan, namun sebenarnya ada ketidakberdayaan perempuan dan ideologi dibalik cerita itu yakni terdapat nilai patriaki di mana laki-laki dianggap superior terhadap kaum perempuan.

Sedangkan kata ucing (kucing) dalam permainan tradisional anak direpresentasikan berkaitan dengan kolektif masyarakat yang menjadi identitas lokal masyarakat Sunda. Banyaknya permainan anak yang dimulai dengan kata ucing sebagai ikon kata dalam permainan tersebut mereprestasikan bahwa kucing merupakan hewan yang terdekat dengan manusia yang berada di dalam rumah maupun di luar rumah. Katakter kucing yang lincah, lucu, baik, namun suka mencuri makanan dengan mengendapngendap dan mengejar-ngejar tikus merupakan simbol bahwa peran yang semestinya dalam kehidupan adalah sosok seperti kucing yang harus lincah 
berjuang untuk melepaskan dari keterpurukan. Hal ini berperan juga sebagai norma-norma sosial dan media pendidikan bagi anak.

Sebenarnya ada satu benang merah dari kajian tentang representasi kucing dalam foklor Sunda cerita Nini Anteh dan permainan tradisional anak, bahwa bagi masyarakat Sunda, kucing dianggap sebagai pembawa petunjuk (cacandran) misalnya jika ada yang menabrak kucing maka akan terjadi bencana, kucing bertengkar diatap menandakan akan terjadi percekcokan, dan jika memandikan kucing akan terjadi hujan deras. Selain itu ada juga mitos bahwa kucing memiliki 9 nyawa dan kucing adalah hewan kesayangan Nabi Muhammad. Adanya cacandran dan mitos ini menjadikan hewan kucing sangat penting bagi masyarakat Sunda. Seperti dalam pandangan hidup orang Sunda disebutkan bahwa orang Sunda melihat adanya hubungan antara dirinya sebagai pribadi; hubungan dirinya dengan Tuhan; dan hubungan dirinya dengan sesama manusia; hubungan dirinya dengan alam. Dari kutipan cerita di atas, dapat dilihat bagaimana orang Sunda memandang dirinya dengan alam (kucing) bahwa manusia hidup harus selaras dengan alam. 


\section{DAFTAR PUSTAKA}

Ahimsa, Shri Heddy. 2010. Esei-Esei Antropologi. Teori, Metodologi dan Etnografi. Yogyakarta: Kepel Press.

Atmadibrata, Enoch, dkk. 1979. Permainan Rakyat Daerah Jawa Barat. Bandung: Pusat Penelitian Sejarah dan Budaya Departemen Pendidikan dan Kebudayaan.

Aminudin, M.Z. 2016. "Penggunaan Peranti Kohesi dalam Cerpen Surat Kabar Jawa Pos Edisi Bulan Januari-Juli 2016". Dalam jurnal Bahasa dan Sastra Indonesia. V.2, 2356-1629.

Ekadjati, dkk. 2000. Ensiklopedia Sunda. Bandung: Pustaka Jaya.

Yostiani, H. 2009. Kajian Struktur, Konteks Penuturan, Fungsi, dan Proses Penciptaan Cerita Nini Anteh di Kotamadya dan Kabupaten Bandung. Skripsi. Bandung: Program Studi Bahasa dan Sastra Indonesia, Universitas Pendidikan Indonesia.

Yostiani, H. 2016. Kajian Struktur, Konteks Penuturan, Fungsi, dan Proses Penciptaan Cerita Nini Anteh di Kotamadya dan Kabupaten Bandung. Skripsi pada Jurusan Bahasa dan Sastra Indonesia FPBS, UPI. (Tidak diterbitkan).

Yostiani, H. 2015. "Transformasi Novel Dongeng Nini Anteh Karya A.S. Kesuma ke Tayangan Opera Van Java Episode Nyai Anteh Penjaga Bulan”. Jurnal Pendidikan Bahasa dan Sastra.

Yostiani, H. 2016. "Transformasi Folklor Nini Anteh ke Novel Dongeng Nini Anteh Karya A.S. Kesuma." Jurnal Pendidikan Bahasa dan Sastra.

Minh-Ha, Trinh. 1989. "Woman, Native, Other: Writing Postcoloniality and Feminism". A Reader of Feminist Literary Theory. Second edition, 394-398.

Praptanto. 2002. Arulin di Pilemburan. Bandung: Tarate.

Prabasmoro, Aquarini Priyatna. 2010. Kajian Budaya Feminis. Tubuh, Sastra, dan Budaya Pop. Yogyakarta: Jalasutra.

Rusyana, dkk. 2000. Ensiklopedi Sastra Sunda. Jakarta: Pusat Pembinaan dan Pengembangan Bahasa. 
Rostiyati, A., Yostiani N.A.H. 2018 "Keterdidikan Perempuan Dalam Cerita Rakyat Nini Anteh" dalam Jurnal ilmiah Patanjala, Vol. 9 No.3 September.

Ratna, N. K. 2013. Teori, Metode dan Teknik Penelitian Sastra. Yogyakarta: Pustaka Pelajar.

Rusyana, Y, dkk. (2000). Prosa Tradisional: Pengertian, Klasifikasi, dan Teks. Jakarta: Pusat Bahasa Departemen Pendidikan Nasional.

Sulistiati, dkk. 1994. Cerita Rakyat Nusantara: Analisis Struktur dan Fungsi Penjelmaan dalam Cerita. Jakarta: Pusat Pembinaan dan Pengembangan Bahasa Departemen Pendidikan dan Kebudayaan.

Sumiyadi, dkk. 2008. Laporan Penelitian Hibah Kompetitif, permainan Tradisional Anak-anak Priangan. Upi: Bandung.

Sunaryo, A. 2009. “Internalisasi Nilai-nilai Tradisi pada Penciptaan Tari Anak Berbasis Budaya Lokal.” Jurnal Pendidikan Bahasa dan Sastra.

Tong, Rosemarie Putnam, 2010. Feminist Thought . Yogyakarta: Jalasutra.

Wiyatmi. 2013. Menjadi Perempuan Terdidik: Novel Indonesia dan Feminisme. Yogyakarta: UNY Press.

\section{Internet}

Agan. 2018. Nini Anteh. Bandung Music Production. [daring] tersedia di: https://www.youtube.com/watch?v=IZojAKUiAfA

Amirin, T.M. (2010). Nini Anteh Sang Penunggu Bulan dan Nini Anteh and Her Cat. [daring] Tersedia di: https://tatangmanguny.wordpress.com/dongeng-sunda/nini -antehsang-penunggu-bulan.html

Ampera, T. (2004). Nini Anteh dalam Perspektif Von Daniken. [daring] Tersedia: http://www.blogtaufikampera.com.

Dixrimination. (2011). Nini Anteh Sang Penunggu Bulan. [daring] Tersedia di: https://m.ngomik.com/comic/7898-nini -anteh-sang-penunggubulan/1-12774/read.html

Rahmawati, Y. (2011). Nini Anteh dalam Wajah Rembulan. [daring] Tersedia di: $\quad$ https://kompasiana.com/post/read/399631//2/nini-anteh-dalamwajah-rembulan.html [diakses pada 10 Desember 2014, pukul 22.10]. 


\section{Daftar Informan:}

$\begin{array}{ll}\text { Nama } & : \text { Nurjanah Yanah } \\ \text { Usia } & : \text { 65 tahun } \\ \text { Alamat } & \text { : Ujung Berung, Bandung } \\ \text { Keahlian } & \text { : Penutur cerita Nini Anteh } \\ \text { Nama } & : \text { Candra Kudapawan } \\ \text { Usia } & : \text { 62 tahun } \\ \text { Alamat } & : \text { Subang }\end{array}$

